\title{
COMPARATION OF SUPPORT VECTOR MACHINE AND ARTIFICIAL NEURAL NETWORK ALGORITHM FOR LECTURER PERFORMANCE CLASSIFICATION
}

\author{
Wowon Priatna ${ }^{1}$, Rakhmat Purnomo ${ }^{2}$ \\ Informatics, Department, Bhayangkara Jakarta Raya University, Jakarta, Indonesia ${ }^{1}$ \\ Informatics, Department, Bhayangkara Jakarta Raya University, Jakarta, Indonesia ${ }^{2}$
}

\begin{abstract}
The purpose of this study is to classify the performance of lecturers from a dataset taken from the bkd.ubharajaya.ac.id application. Many universities have not been effective in assessing the performance of lecturers so that the data that has been obtained from each lecturer's report only becomes stored data, not yet into knowledge that will be used as decision makers. The research method used in this research is to start by acquiring data from the bkd.ubharajaya.ac.id application which will then be analysed through data mining stages by pre-processing data that is feasible to create a dataset. The dataset that has been created is then analysed using the 10 -fold cross validation method which will divide the data into training data and testing data which will then be made a classification model using the Support Vector Machine (SVM) and Artificial Neural Network (ANN) algorithms. The expected research results with this application can classify the performance of lecturers who have the best accuracy to be used as a decision-making system.
\end{abstract}

Keywords: Lecturer Performance, Artificial Neural Network, Support Vector Machine, 10-Fold Cross Validation, Classification

\section{INTRODUCTION}

The performance of lecturers in higher education is tangible evidence produced by lecturers as achievements that are intended according to their roles. Lecturer performance appraisal refers to a formal and structured system to measure, assess, and influence the characteristics related to their work. Thus the assessment is the result of the work of personnel and their responsibilities[1].

Higher education has the goal of producing quality graduates. Therefore, competent teaching staff are needed in teaching [2]. At a university, all of them hold assessment techniques for their lecturers, to get outstanding lecturers so that they can be awarded with the aim of giving the lecturer morale, and being an example for other lecturers [3].

Bhayangkara University Jakarta Raya is one of the universities in Jakarta which has 6 faculties and consists of 14 study programs. To produce outstanding students requires qualified lecturers. To measure the performance of lecturers, Bhayangkara University requires lecturers to report the burden of lecturer performance each semester by requiring lecturers to report their performance through the web application www.bkd.ubharajaya.ac.id. To map the performance of each lecturer, it is necessary to classify each assessment indicator.

\section{RELATED WORK}

One method for classifying data is the Support Vector Machine (SVM) and Artificial Neural Network (Sihombing \& Oki Prasetia Hendarsin, [4] algorithm. Research [5] uses SVM for classification in determining the optimal search value. Svm is also used in the classification of Diabetes data, Heart Data, Satellite Data and Shuttle Data) resulting in accuracy showing comparative results using different kernel functions for all data samples [6]. For classification can also use neural network algorithms such as research [7] because it is able to study non-linear models and large data. Artificial neural network is used to classify lecturers' performance on mastery of teaching materials by producing better accuracy [8]).

Research [9] uses neural networks and support vector machines to classify PDAM company performance data. /day, and Ratio of Number of Employees/1000 customers with an average accuracy of $83.93 \%$ and a prediction precision level for Unhealthy performance of $86.36 \%$. This is better when compared to the 


\section{III.METHODOLOGY}

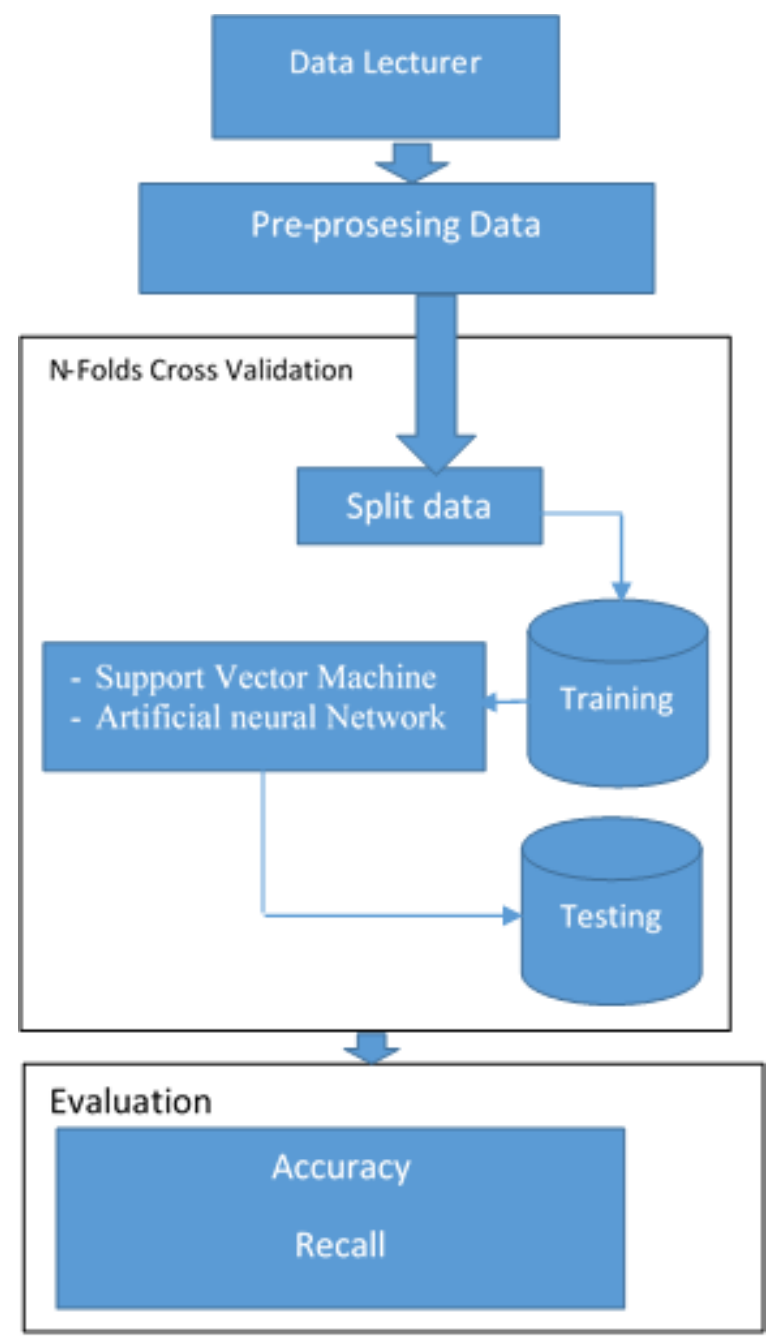

Figure 1: Architecture of the Proposed System

The data collection technique used in this study is the lecturers' performance reports which are reported through the lecturer's performance burden in one semester. Based on Figure 1, data analysis is carried out after the data collection process by pre-processing by doing data cleansing so that the data obtained will maximally produce good patterns to be processed in data mining algorithms. The data is divided into training data and testing data, then training is carried out using a support vector machine algorithm and an Artificial Neural network. The results of the model will get accuracy and recall from the two algorithms.

\section{IV.DISCUSSION OF RESULT}

Pre-processing data is the first step in an analysis to check and correct when there is a missing value before starting the learning process. When a data contains information that is not available on one or more object variables or certain cases, data correction will be carried out. The examination of missing data in this study uses the Python programming language. The df.isnull().sum() and df.shape functions to ensure that there is no empty data in the dataset to be processed. Table 1 results from processing missing data using python. Transforming the data used, and dividing the data into two parts (data partition). 
International Journal of Advanced Research in Computer and Communication Engineering

Vol. 10, Issue 9, September 2021

DOI: $\quad$ 10.17148/IJARCCE.2021.10901

TABLE I CHECK DATA MISSING

\begin{tabular}{|l|l|l|l|}
\hline Variable & Valid & Missing & Percentage \\
\hline Pengajaran (Teaching) & 315 & 0 & $100 \%$ \\
\hline $\begin{array}{l}\text { Penelitian dan Publikasi } \\
\text { (Research and Publication) }\end{array}$ & 315 & 0 & $100 \%$ \\
\hline Pengabdian (Devotion) & 315 & 0 & $100 \%$ \\
\hline Penunjang(Support) & 315 & 0 & $100 \%$ \\
\hline $\begin{array}{l}\text { Rata-Rata Index (Average } \\
\text { Index) }\end{array}$ & 315 & 0 & $100 \%$ \\
\hline
\end{tabular}

Data transformation Using the function scaler $=$ StandardScaler(), we get the data from the data transformation with a scale of -1 to 1 as presented in Appendix 2. After the transformation results are obtained, we can proceed to the next step, namely data sharing. Split data In this step, divide the training data and testing data using the function from sklearn.model_selection import train_test_split $X \_t r a i n, X \_t e s t, y \_t r a i n, y \_t e s t ~=$ train_test_split(X, y, test_size $=0.2$, random_state $=1$ ) python. With specifications $80 \%$ training data and $20 \%$ testing data. Prediction results using SVM can be seen in table 2 .

TABLE 2 FONT SIZES FOR PAPERS

\begin{tabular}{|c|l|l|l|}
\hline \multirow{2}{*}{ Fold Ke- } & \multicolumn{3}{|c|}{ Kernel Function Accuracy } \\
\cline { 2 - 4 } & Linear & Polynomial & Radial Basis Function (RBF). \\
\hline 8 & $93 \%$ & $92 \%$ & $97,4 \%$ \\
\hline 9 & $93,4 \%$ & $93 \%$ & $98 \%$ \\
\hline 10 & $90 \%$ & $92 \%$ & $97,7 \%$ \\
\hline Average & $92.1 \%$ & $92.3 \%$ & $97.7 \%$ \\
\hline
\end{tabular}

Table 2 shows that the calculation of the accuracy of lecturer performance classification using SVM with various kernel functions has a fairly good accuracy value. From the calculation of 10 -fold cross validation for this accuracy, the highest average percentage of accuracy is the SVM prediction with the RBF Kernel function of 97.7\%. The second best percentage of accuracy is the implementation of SVM using the Polynomial Kernel of $92.3 \%$, followed by the use of Linear Kernel with the percentage of accuracy of $92.1 \%$. while the results of the classification using python get the recal results obtained an average score of 0.50 , the average recall value gets a score of 0.34 while the accuracy value gets a value of 0.52

To build a model for ANN classification, several things are important to build a model in an artificial neural network: input, function, hidden layer, activation, output. In this study using 4 inputs from variable $\mathrm{x}$ and output from variable $\mathrm{y}$. hidden layer uses 5 hidden layers (dense), while the activation function is relu, softmax. To get the classification prediction result model using $\mathrm{ANN}$ use the function in python: history=model.fit(X_train, Y_train, validation_data $=\left(X \_t e s t, Y \_\right.$test $)$,epochs $=50$, batch_size $\left.=10\right)$. the results of the training data show the value of accuracy, lost validation, validation of accuracy of the trained data, while the training was carried out for 50 epochs. The classification result generated by ANN is 0.9.

\section{Conclusion}

In the classification of lecturer performance using a support vector machine using 3 kernels, namely: linear, polynomial and RBF. While in ANN the kernel function here is the activation function, the activation functions used are relu and softmax. The results of the accuracy of lecturer performance classification using ANN get the highest accuracy of 0.9 while SVM gets an accuracy of 0.5. then the recommendation for the classification of lecturer performance using the ANN algorithm.

\section{REFERENCES}

[1]. Adi Suwasono, D. (2016). Sistem Evaluasi Kinerja Dosen. Matangglumpangdua: Universitas Almuslim.

[2]. Afif, M. H., \& Hedar, A. R. (2012). Data classification using support vector machine integrated with scatter search method. Proceedings of the 2012 Japan-Egypt Conference on Electronics, Communications and Computers, JEC-ECC 2012, 168-172. https://doi.org/10.1109/JECECC.2012.6186977 


\section{International Journal of Advanced Research in Computer and Communication Engineering}

Vol. 10, Issue 9, September 2021

\section{DOI: $10.17148 /$ IJARCCE.2021.10901}

[3]. Alkhasawneh, R., \& Hobson, R. (2011). Modeling student retention in science and engineering disciplines using neural networks. 2011 IEEE Global Engineering Education Conference, EDUCON 2011, 660-663. https://doi.org/10.1109/EDUCON.2011.5773209

[4]. Alloghani, M., M. Alani, M., Al-Jumeily, D., Baker, T., Mustafina, J., Hussain, A., \& J. Aljaaf, A. (2019). A systematic review on the status and progress of homomorphic encryption technologies. Journal of Information Security and Applications, 48(October). https://doi.org/10.1016/j.jisa.2019.102362

[5]. Alzubi, J., Nayyar, A., \& Kumar, A. (2018). Machine Learning from Theory to Algorithms: An Overview. Journal of Physics: Conference Series, 1142(1). https://doi.org/10.1088/1742-6596/1142/1/012012

[6]. Bernard, J., Chang, T. W., Popescu, E., \& Graf, S. (2015). Using artificial neural networks to identify learning styles. Lecture Notes in Computer Science (Including Subseries Lecture Notes in Artificial Intelligence and Lecture Notes in Bioinformatics), 9112(June), 541-544. https://doi.org/10.1007/978-3-319-19773-9_57

[7]. Frieyadie. (2018). Metode AHP Sebagai Penunjang Keputusan Untuk Penilaian Kinerja Kerja Karyawan SPBU. Jurnal TECHNO Nusa Mandiri, 15(1), 63-68. Retrieved from http://ejournal.nusamandiri.ac.id/ejurnal/index.php/techno/article/view/840/pdf

[8]. Guleria, P., Thakur, N., \& Sood, M. (2015). Predicting student performance using decision tree classifiers and information gain. Proceedings of 2014 3rd International Conference on Parallel, Distributed and Grid Computing, PDGC 2014 , $126-129$. https://doi.org/10.1109/PDGC.2014.7030728

[9]. Ha, D. T., Giap, C. N., Loan, P. T. T., \& Huong, T. L. H. (2020). An Empirical Study for Student Academic Performance Prediction Using Machine Learning Techniques. International Journal of Computer Science and Information Security, 18(3), 21-28. 